Personalidade Acadêmica Homenageada:

Raymundo Juliano Feitosa (Universidade Federal do Rio Grande do Norte - UFRN)

\title{
O ESTADO E A LEGITIMAÇÃO DOS OITENTA TIROS: O NOVO PACOTE ANTICRIMES E SUAS (IN) COSTITUCIONALIDADES
}

\section{THE STATE AND LEGITIMATION OF THE EIGHTS SHOOTING: THE NEW ANTI-CRIME PACKAGE AND IT'S (IN) COSTITUTIONALITIES}

\section{LIZ MARTINS DA CONCEIÇÃO}

Graduanda em Direito, modalidade integral, pela Escola Superior Dom Helder Câmara. Belo Horizonte-MG. E-mail: lizmartinsc@icloud.com

\section{CAIO AUGUSTO SOUZA LARA}

Mestre e Doutor em Direito pela Faculdade de Direito da Universidade Federal de Minas Gerais - UFMG. Professor da Escola Superior Dom Helder Câmara. Pesquisador Associado ao Programa RECAJ-UFMG - Acesso à Justiça e Solução de Conflitos. Secretário de Comunicação do Conselho Nacional de Pesquisa e Pósgraduação em Direito - CONPEDI. Belo Horizonte-MG. E-mail: caiolarabh@yahoo.com.br.

\section{RESUMO}

O tema-problema da pesquisa em desenvolvimento é o estudo das características, pontos positivos e negativos Pacote Anticrime apresentado pelo Ministro Sérgio Moro. O enfoque é a análise de pontos positivos e negativos da proposta, como o poder do pacote em legitimar a violência policial e ferir direitos assegurados na Constituição. A motivação para realizar essa pesquisa foram as inúmeras críticas que o pacote sofreu na doutrina especializada. O criminalista Antônio Carlos de Almeida Castro chega a afirmar que o projeto é absolutamente frustrante, pois ao recrudescer a legislação penal, ele fere diversos direitos 
Personalidade Acadêmica Homenageada:

Raymundo Juliano Feitosa (Universidade Federal do Rio Grande do Norte - UFRN)

consolidados ao longo dos séculos. Dentre todas as negatividades apontadas por especialistas, os pontos mais criticados do projeto dizem respeito à ampliação das hipóteses em que um crime cometido por um policial pode ser considerado legítima defesa e a falta de atenção com a superlotação das cadeias brasileiras. Sendo assim, analisa-se como problema objeto da investigação científica proposta: existem inconstitucionalidades no pacote anticrimes apresentado? A proposta de ampliação das hipóteses em que um crime cometido por um policial pode ser considerado legítima defesa pode aumentar o abuso de violência policial? Quais os pontos positivos da mudança proposta? A partir das reflexões preliminares sobre o tema, é possível afirmar inicialmente que algumas das alterações no Código Penal, propostas pelo atual Ministro da Justiça não são constitucionais e que as mudanças nas excludentes de ilicitude dão margem para o abuso de poder por parte dos policiais. Entretanto, não se pode afirmar previamente que essas suposições sejam verdadeiras, tendo em vista que a pesquisa se encontra em estágio inicial de desenvolvimento. Além disso, o trabalho do ministro também recebe críticas positivas, que devem ser consideradas. Desse modo, materiais doutrinários serão estudados com o objetivo de verificar se tais hipóteses são verdadeiras. Para tal verificação, primeiramente, são analisadas as alterações propostas pelo Sergio Moro no Código Penal e essas serão analisadas sob a luz dos artigos da Constituição da República Federativa do Brasil de 1988. Ademais, esta pesquisa objetiva constatar futuros impactos sociais dessas medidas, sendo eles tanto a efetividade das medidas para combater os crimes que assolam a sociedade brasileira, bem como a intensificação da crise do sistema penitenciário e o aumento da, já tão praticada, violência policial. A pesquisa que se propõe pertence à vertente metodológica jurídico-sociológica. No tocante ao tipo de investigação, foi escolhido, na classificação de Witker (1985) e Gustin (2010), jurídico-projetivo. O raciocínio desenvolvido na pesquisa será predominantemente dialético. De acordo com a técnica de análise de conteúdo, afirma-se que se trata de uma pesquisa teórica, o que será possível a partir da análise de conteúdo dos textos doutrinários, normas e demais dados colhidos na pesquisa. Por meio desses estudos até agora realizados, tem-se como conclusão parcial do trabalho que uma mudança no Código Penal pode ser necessária, pois esse se mostra 
Personalidade Acadêmica Homenageada:

Raymundo Juliano Feitosa (Universidade Federal do Rio Grande do Norte - UFRN)

ineficiente, já que os crimes crescem consideravelmente no Brasil e preocupam toda a população. Entretanto, certos pontos do documento proposto por Sérgio Moro, mesmo que não objetivem, podem ter como consequências impactos sociais que firam os Direitos Humanos. Essa afirmação se dá porque ao propor prisão após segunda instancia de julgamento e considerar isento de culpa o policial que previne a agressão ou age sob forte emoção, tem-se como impacto social, respectivamente o aumento dos problemas de crise do sistema penitenciário e do abuso de poder policial, que culminam na violação do artigo quinto da constituição.

PALAVRAS-CHAVE: Direito Penal; excludente de ilicitude; Direitos Humanos; violência policial.

\section{REFERÊNCIAS}

BENITES, Afonso. Plano Moro afrouxa regras para policiais que matam e sugere medidas que já foram barradas. Portal El País. 4 de fevereiro de 2019. Disponível em: https://brasil.elpais.com/brasil/2019/02/04/politica/1549311947_740805.html. Acesso em: 9 de maio de 2019.

BRASIL. Constituição da República Federativa do Brasil de 1988. Disponível em: http://www.planalto.gov.br/ccivil_03/constituicao/constituicaocompilado.htm. Acesso em: 10 de maio de 2019.

BRASIL. Decreto-Lei No 2.848, de 7 de Dezembro de 1940. Dispõe sobre o código Penal brasileiro. Disponível em: http://www.planalto.gov.br/ccivil_03/decretolei/del2848compilado.htm. Acesso em: 10 de maio de 2019.

BRASIL. Ministério da Justiça. (1997), Programa Nacional de Direitos Humanos. Brasília: Ministério da Justiça.

GUSTIN, Miracy Barbosa de Sousa; DIAS, Maria Tereza Fonseca. (Re)pensando a pesquisa jurídica: teoria e prática. 3ª ed. Belo Horizonte: Del Rey, 2010.

LELIS, Henrique Rodrigues; LOBÔ, Edilene. A dimensão cultural dos Direitos Humanos e a efetivação democrática de Direito. Revista Jurídica - UNICURITIBA, Curitiba, v.3, p 734-738, 2016. 
Personalidade Acadêmica Homenageada:

Raymundo Juliano Feitosa (Universidade Federal do Rio Grande do Norte - UFRN)

SHALDERS, André. 'Pacote Anticrime' de Sergio Moro: porque alguns advogados e juristas questionam a proposta. Portal BBC News. 4 de fevereiro de 2019. Disponível em: https://www.bbc.com/portuguese/brasil-47125522. Acesso em: 10 de maio de 2019.

WITKER, Jorge. Como elaborar una tesis en derecho: pautas metodológicas y técnicas para el estudiante o investigador del derecho. Madrid: Civitas, 1985. 